\title{
Accountancy Performance and Achievement (Accountancy Development Index), Case of
} Albania

\author{
Brisejda RAMAJ ZENUNI MSc. \\ $\mathrm{PhD}$ Candidate at the Department of Accounting, University of Tirana, Faculty of Economy, Lecture in Financial and \\ Accounting Department, University of Vlora "Ismail Qemali", Faculty of Economy, Vlore, Albania
}

Mirela UJKANI MITI, PhD

Lecture on Accaunting Departament, Faculti of Economics University of Tirana Albanian, Tirana, Albania

\begin{abstract}
The transparency and quality of audits performed by professional accountants and auditors are of crucial importance for the functioning of the global financial infrastructure. Over de last decade, more and more auditors were confronted with the globalization of their clients and became so-called group auditors responsible for the overall quality of the audit engagement even if other auditors in other jurisdictions may be involved. It goes without saying that auditors around the globe do not work in the same environment, do not have to comply with the same rules and regulations and do not have the same level of education before they can apply for an audit license. The qualification, education, training and experience of professional accountants and auditors are of crucial importance for the functioning of the global financial infrastructure. A wide range of stakeholders, including regulators and standard setters, professional accountancy organizations and accountancy firms as well as issuers of financial reports and users of accounting services depend on their professional expertise. The Evaluation of the situation of accountancy education with its components of qualification, education and training in selected countries and Ballcan compared with the requirements of the IES. The status of accountancy education with its components of qualification, education and training in Albania (Accountancy Development Index). The (ADI) illustrates how adoption and implementation of international standards can be visualized for all pillars of the global financial infrastructure and how separate pillar scores can be used to clarify results at the sub-pillar or milestone level.
\end{abstract}

Keywords: Accounting Performance, Accountants and Auditors, Professional Education. Disciplines Accounting JEL classification: M41, M48, I22, I23, I25, A23

\section{Introduction}

The transparency and quality of audits performed by professional accountants and auditors are of crucial importance for the functioning of the global financial infrastructure. A wide range of stakeholders, including regulators and standard setters, professional accountancy organizations and accountancy firms as well as issuers of financial reports and users of accounting services depend on their professional expertise. Global financial markets are asking for global financial statements with an opinion of an independent auditor. Over the last decade, more and more auditors were confronted with the globalization of their clients and became so-called group auditor. Still the group auditor remains responsible for the overall quality of the audit engagement the group auditor is assigned to even if other auditors may be involved. It goes without saying that auditors around the globe do not work in the same environment, do not have to comply with the same rules and regulations and do not have the same level of education before they can apply for an audit license. That's even in the case of audit firms with global connections, strict or loose organized in networks. So as a consequence of globalization a very important question arises namely:

To what extend can an auditor rely on the work performed or an opinion issued by another auditor in another jurisdiction?

This question of globalization was discussed in the International Auditing and Assurance Standards Board (IAASB) of the International Federation of Accountants (IFAC) during the clarity project. At the same time some cases related to this 
question were taken to court. The question became one of the leading principles in redrafting the International Standard on Auditing (ISA) 600: Special Considerations-Audits of Group Financial Statements (Including the Work of Component Auditors).

In foreign jurisdictions there might be a situation of unusual governmental intervention in areas such as trade and fiscal policy, or restrictions on currency. How sure can the group auditor be that the component auditor is knowledgeable of that situation? To rely on the work of the component auditor the group-auditor has to have enough knowledge about the quality of the work of the component auditor. To get those knowledge he should have among others an understanding of the environment the component auditor is working in, the relevant rules and regulations that apply in that jurisdiction and the education required to get a license in that jurisdiction. The last couple of years the accountancy profession stands in the middle of the spotlights when it comes on performing a quality audit. Time after time the group auditor is running the risk to issue his auditor's opinion whiteout the appropriate high quality audit evidence as a basis.

\section{The need to "Restoring the trust"}

As we all know, we are living in a time frame in which boundaries disappear and globalization is the key word. Business is driven by global markets. Global financial markets are asking for global financial statements with an auditor's opinion. Over the last decade, more and more auditors were confronted with the globalization of their clients and had to rely on the work of other auditors in other jurisdictions than their own. To rely on the work of those auditors the group-auditor has to have enough knowledge about the quality of the work of the other auditor, called the component auditor. To get those knowledge the group auditor should have among others an understanding of the environment the component auditor is working in, the relevant rules and regulations that apply in that jurisdiction and the education required to get a license in that jurisdiction. The predecessors of the Global Accountancy Development Institute started in 1999 to bring together information about the global professional education of accountants and auditors, resulting in 2002 in the first publication. Global Accountancy Transparency Information (GATI) is an innovative look and proxy for the condition of the accountancy development in a country. GATI will be data rich, allows the user to drill down on compliance gaps and will help to inform future actions. GATI will collect relevant data, will maintain the data and will make the data available for auditors in practice to comply with ISA 600 and for all other interested parties. GATI measures eight aspects of a country transparency and accountancy infrastructure, called Pillars, divided into Subpillars, Milestones and Indicators if applicable. Through a quantitative approach the complex, multidimensional economic and social phenomena indices are per Pillar reduced to a level of adoption and implementation in regard to applicable international standards. After all the Pillar data are processed per country an overall level of compliance will be available.

The eight mentioned not independent but interrelated Pillars are:

Pillar 1, Legal, Regulatory and Institutional Framework

Pillar 2, Audit, Assurance and Quality Control

Pillar 3, Professional Accountancy Education

Pillar 4, International Public Sector Accounting Standards

Pillar 5, International Financial Reporting Standards

Pillar 6, Ethics \& Discipline

Pillar 7, Corporate Governance - Integrated Reporting

Pillar 8, Professional Accountancy Association Institutional Capacity

To facilitate more disaggregated analysis, each pillar can be considered separately. This approach is intended to be useful as an aid to decision-making and as an important element of accountancy and transparency, created for the purpose of assisting future change and progress.

\section{Monitoring Country Progress,}

Monitoring country progress to meet development goals stands as one of the fundamental processes of evaluation leading to program design and implementation. Performance indicators may be grouped into convenient categories such as 
economic growth, economic reforms, democratic reforms, etc. At the heart of these indicators are quantitative measurements, frequently using indices, to measure achievement within the realm of adoption and implementation of predetermined benchmarks such as internationally recognized standards and best practices.

Incentives for the international community of donors to support development are based on an objective measurement of progress. Critics of development assistance frequently site the diffuse, uncoordinated and unsustained aspects of many reform projects. These same critics suggest that better situation assessments be made, more comprehensive monitoring and evaluation tools be developed and proactive measures taken during projects to adjust for new realities. Measurement can be a tool that quantifies and documents capacity building progress over time, which is a key feature of sustained economic development. Ideally, performance measurement can be used to develop results frameworks and a set of performance indicators at the project level. An action-oriented, results framework that links project level indicators to intermediate and higher level indicators of country progress in building sustainable capacity are imperative in today's resource allocation decisions.

\section{Accountancy Infrastructure}

Integral to sustained economic growth is a trusted, reliable financial architecture, and integral to this architecture is an accountancy infrastructure that serves the public interest. It is against this backdrop that the Accountancy Development Index (ADI) was developed. It is an innovative look and a proxy for the condition of the accountancy development in a country. It measures many aspects of a country's transparency and accountability infrastructure through a quantitative composite index. A balance sheet of a country's accountancy development- its assets (achievements) and its liabilities (compliance gaps) summarized into its net worth (index). A balance sheet is a "snapshot" in time. The ADI would use this date in time to measure progress as future updates are solicited. It can be used to recognize reformers and conversely, those that regress. As a development tool it will serve as yet another means of focused programming in an era of limited international funds/resources.

Measuring economic growth and accountancy reforms would not be complete without considering the importance of the accountancy profession on capital formation and foreign direct investment. Essentially, at the end of the accountancy value chain is the financial report. In the ADI context, a financial report includes both a private enterprise or of a public agency. It is well recognized that general purpose financial reporting, both public and private, plays a critical role in the financial architecture of today's global economy. In order to serve the public interest, financial reports (the foundation of information for investment analytics) must provide unbiased, transparent and relevant information about the economic performance and condition of businesses and public entities. Effective financial reporting depends on high quality accounting standards as well as the consistent and faithful application and rigorous enforcement of those standards.

Figure 1: Accountancy Environment illustrates the many facets of the accountancy environment.

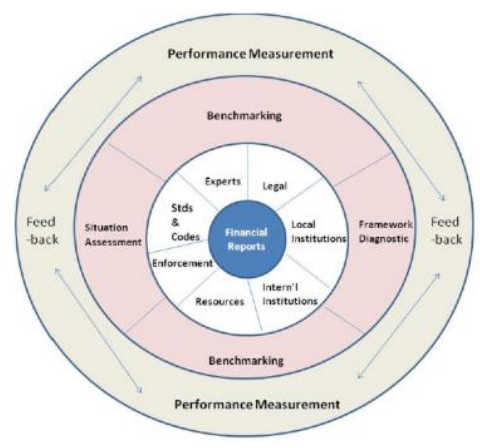

Source: Measuring Country-Level Accountancy Performance and Achievement (2012)

ADI is designed around internationally accepted standards and best practices and, for the first time, provides a simple, comprehensive quantitative summary about a country's accountancy environment. This environment includes a country's adoption and implementation of accounting, auditing, governance, legal and institutional capacity standards and best 
practices that may be used by a wide audience. It is flexible because of its design around eight pillars that are independently "scored" with features that grab the audiences' attention through strong data visualization.

The audience includes donor agencies, standard setters, regulators, professional associations, educators, pundits, and other capital market participants whose use and benefit is illustrated in the following Table1:

\begin{tabular}{|c|c|c|}
\hline Stakeholder & Primary Use & Primary Benefit \\
\hline Standard Setters & $\begin{array}{l}\text { Determine status of adoption and } \\
\text { implementation }\end{array}$ & $\begin{array}{l}\text { Improve standards, communication } \\
\text { and outreach }\end{array}$ \\
\hline $\begin{array}{l}\text { Professional Accounting \& } \\
\text { Auditing Associations }\end{array}$ & $\begin{array}{l}\text { Inform initiatives to close } \\
\text { compliance gaps }\end{array}$ & Improved financial reporting \\
\hline Government Agencies & $\begin{array}{l}\text { Identify changes to laws, rules and } \\
\text { regulations }\end{array}$ & $\begin{array}{l}\text { More favorable capital markets } \\
\text { recognition }\end{array}$ \\
\hline Regulators & Identify non compliance & $\begin{array}{l}\text { Improve enforcement and reduce } \\
\text { negative capital markets ratings }\end{array}$ \\
\hline Donors & $\begin{array}{l}\text { Identify strategic priorities for } \\
\text { assistance }\end{array}$ & $\begin{array}{l}\text { Targeted assistance yielding } \\
\text { sustained results }\end{array}$ \\
\hline Educators & $\begin{array}{l}\text { Improve curriculum and relations } \\
\text { with accountancy profession }\end{array}$ & $\begin{array}{l}\text { Greater understanding of current } \\
\text { financial realities }\end{array}$ \\
\hline Investors & Align risks and pricing & $\begin{array}{l}\text { Better understanding of country } \\
\text { risk profiles }\end{array}$ \\
\hline
\end{tabular}

Source: ADI pilot study (Phelps, 2011) performance measurement data and analyses

The ADI took over two years to develop by a dedicated design/research team, guided by a Steering Council of international experts and aided by country respondents, volunteers and funded by USAID. A pilot group of 40 countries were asked to participate in the testing and evaluation. It should be stressed that this was a pilot initiative and was conducted knowing that some design features will require further research and development. For the ADI to continue beyond this pilot initiative, it must be seen by the primary stakeholders as a tool that aids in accelerating the adoption and implementation of international accountancy standards and best practices.

\section{The Eight Pillars of Transparency and Accountability}

Recognizing the subjectivity of measurement, the uniqueness of country economic and legal characteristics and the public interest objective of financial reporting, the ADI takes a holistic view of the accountancy infrastructure or more broadly viewed as the accountancy environment. The accountancy environment is defined as the set of institutions, laws, policies, standards, and best practices that determines the quality of financial reporting, both public and private.

The ADI is constructed as a single index drawn from each of eight pillars. However, to facilitate more disaggregated analysis, each pillar is its own index. This comparative set of layered indices is more useful as an aid to decision-making and as an important element of accountability and transparency, created for the purpose of assisting future change and progress.

In reality, the pillars are not independent but are interrelated and reinforcing although there are many benefits to using indices to measure and convey information, there are some areas of concern that must be considered. Indices are much like mathematical or computational models. As such, their design is dictated more by the craftsmanship of the modeler than to universally-accepted scientific rules for their construction. In addition, no index can include every possible variable and therefore, the picture the modeler creates is always relative or somewhat incomplete. Also, improper construction in regards to the inclusion and exclusion of certain indicators and inappropriate choices regarding sensitivity, weighting and aggregation techniques and missing data can result in a distorted picture of a situation.

Observable benchmarks-standards and best practices 
The development of the ADI methodology turned initially on the benchmarks that would be used for the framework. Standard setters for the accountancy profession (IFAC and IASB) have developed international standards for accounting, auditing, ethics, education, and discipline. These standards were developed through an exhaustive process of research, consultation, outreach to stakeholders, and oversight. Collaboration, communication and strategic alignment with the public interest are hallmarks of the standard setting process.

In addition to the country's legal/regulatory environment, the reputation, expertise, and capabilities of the institutions from which these standards and best practices were derived are also important. These include:

- International Federation of Accountants (IFAC) Statements of Membership Obligations (SMO);

- OECD Principles of Corporate Governance - V. Disclosure and Transparency;

- World Bank Public Expenditure Financial Assessment (PEFA) Reports;

-World Bank Accounting and Auditing Reports on the Observance of Standards and Codes (ROSC);

- USAID NGO Sustainability Index;

- EU 8th Directive.

Table 2: Pillar Outline further illustrates the ADI design framework and outlines the pillars and milestones.

\begin{tabular}{|c|c|c|c|}
\hline $\begin{array}{c}\text { I.0 } \\
\text { Legal, Regulatory and } \\
\text { Institutional Framework }\end{array}$ & $\begin{array}{l}2.0 \\
\text { Audit, Assurance, and } \\
\text { Quality Control }\end{array}$ & $\begin{array}{c}3.0 \\
\text { Professional Education }\end{array}$ & $\begin{array}{c}4.0 \\
\text { International Public } \\
\text { Sector Accounting } \\
\text { Standards }\end{array}$ \\
\hline $\begin{array}{c}\text { The legal and regulatory } \\
\text { environment as it relates to } \\
\text { accountancy. }\end{array}$ & $\begin{array}{l}\text { International standards, } \\
\text { procedures \& best practices for } \\
\text { the provision of high quality audit, } \\
\text { assurance, review, \& related } \\
\text { services. }\end{array}$ & $\begin{array}{l}\text { Adoption \& Implementation of } \\
\text { International standards for } \\
\text { accountancy education, } \\
\text { practical experience, } \\
\text { assessment and continuing } \\
\text { professional education. }\end{array}$ & $\begin{array}{l}\text { Adoption and implementation of } \\
\text { IPSAS }\end{array}$ \\
\hline $\begin{array}{l}\text { 1.01 Accounting \& Auditing } \\
\text { Framework } \\
\text { 1.02 Public Sector Framework } \\
\text { 1.03 Public Oversight } \\
\text { 1.04 Licensing Arrangements }\end{array}$ & $\begin{array}{c}2.01 \text { International Standards on } \\
\text { Audit (ISA) } \\
2.02 \text { International Standards on } \\
\text { Assurance (ISAE) } \\
2.03 \begin{array}{c}\text { International Standards on } \\
\text { Review Engagement (ISRE) }\end{array} \\
\begin{array}{c}2.04 \text { International Standards on } \\
\text { Related Services (ISRS) }\end{array} \\
\begin{array}{c}2.05 \text { International Standards on } \\
\text { Quality Control (ISQCI) }\end{array} \\
2.06 \text { Quality Control at the Firm Level } \\
2.07 \text { Quality Control at the Partner } \\
\text { Level } \\
2.08 \text { System of Quality Assurance }\end{array}$ & $\begin{array}{l}\text { 3.01 Entry Requirements } \\
\text { 3.02 Program Content } \\
\text { 3.03 Professional Skills } \\
\text { 3.04 Values, Ethics, Attitudes } \\
\text { 3.05 Assessment } \\
\text { 3.06 Practical Experience } \\
\text { 3.07 Continuing Professional } \\
\text { Development }\end{array}$ & $\begin{array}{l}\text { 4.01 Public Sector Accounting } \\
\text { Environment } \\
4.02 \text { Comprehensiveness \& } \\
\text { Transparency of PFM } \\
\text { 4.03 External Audit of Government } \\
\text { Annual Financial Statements } \\
\text { 4.04 IPSAS Accounting Programs } \\
4.05 \text { IPSAS Monitoring \& Enforcement }\end{array}$ \\
\hline $\begin{array}{l}\mathbf{5 . 0} \\
\text { International Financial } \\
\text { Reporting Standards }\end{array}$ & $\begin{array}{c}6.0 \\
\text { Code of Ethics, } \\
\text { Investigation } \& \text { Discipline }\end{array}$ & $\begin{array}{c}7.0 \\
\text { Corporate Governance } \\
- \text { Transparency } \& \\
\text { Disclosure }\end{array}$ & $\begin{array}{c}8.0 \\
\text { Professional Accountancy } \\
\text { Association Institutional } \\
\text { Capacity }\end{array}$ \\
\hline $\begin{array}{l}\text { 5.01 Private Sector Accounting } \\
\text { Environment } \\
5.02 \text { IFRS Monitoring \& Enforcement }\end{array}$ & $\begin{array}{l}\text { Principles of professional ethics } \\
\text { for accountancy professionals and } \\
\text { processes for bringing to account } \\
\text { professionals who fail to maintain } \\
\text { high professional standards. } \\
6.01 \text { Creation of a Code of Ethics } \\
\text { (COE) } \\
6.02 \text { The ethical environment } \\
6.03 \text { Investigation Process } \\
6.04 \text { Disciplinary Process } \\
6.05 \text { Appeals Process }\end{array}$ & $\begin{array}{l}\text { The framework of rules and } \\
\text { practices by which firms ensure } \\
\text { accountability, fairness, and } \\
\text { transparency in its operations. } \\
7.01 \text { Material Disclosures } \\
7.02 \text { Annual Audit } \\
7.03 \text { Auditor Accountability } \\
7.04 \text { Information Dissemination } \\
7.05 \text { Provision of Information }\end{array}$ & $\begin{array}{l}\text { The efficiency and effectiveness of } \\
\text { professional accounting / auditing } \\
\text { association operations }\end{array}$ \\
\hline
\end{tabular}

Source: Measuring Country-Level Accountancy Performance and Achievement Accountancy Development Index 
The ADI includes questions that measure a country's change/improvement in a certain pillar or sub-pillar. These questions are not incorporated into ADI scores as the index is designed to provide a point-in-time measure of accounting environments across countries.

Adoption of international standards is based on a decision that the international standard is appropriate for use in the national financial reporting environment. Implementation is concerned with the practical steps necessary to make use of the standards. As a result, quite different actions are necessary to achieve each step in a meaningful way.

Figure 2 overlays the achievements of developing nations with those of the more developed nations. The differences between the eight ADI pillars are highlighted.

\section{Figure 2: ADI Developed and Developing Nations}

\section{Accountancy Development Index}

Developed vs. Developing Nations

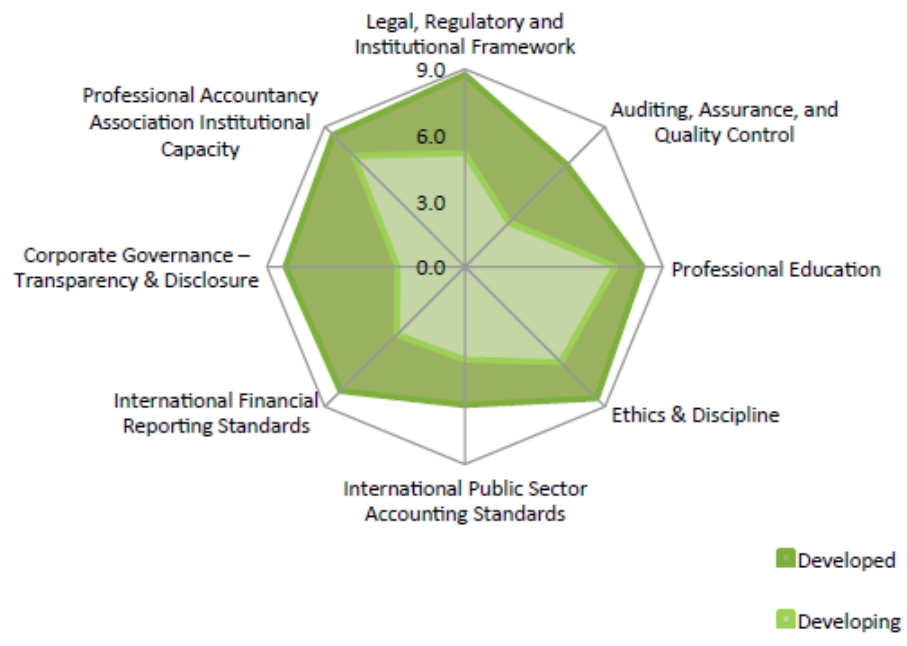

Source: Measuring Country-Level Accountancy Performance and Achievement Accountancy Development Index

The following Figure 3 illustrates the differences, by pillar, of adoption and implementation of standards within the same country. 
Figure 3: Spider Graph Example Adoption vs. Implementation

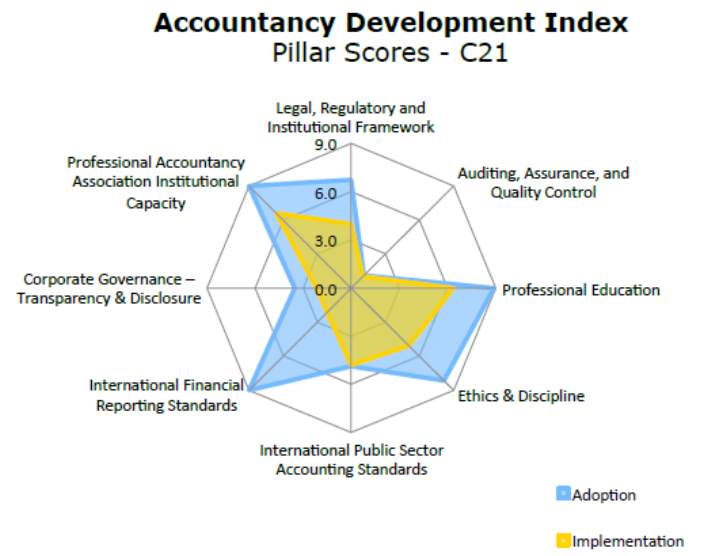

Source: Measuring Country-Level Accountancy Performance and Achievement Accountancy Development Index

\section{The case of Albania}

Accountancy is the practice of identifying, measuring, and communicating financial information about economic entities to interested persons (users). The ultimate goal of accountancy is the provision of financial information to enhance the economic decision-making of users. As such, it functions to fairly and accurately illustrate the financial position and operations of an entity, and thereby provide information useful in making investment and credit decisions, assessing cash flows, and measuring an entity's resources. Through the provision of this information and its impact on economic decisionmaking accountancy enhances corporate governance, competition, the functioning of capital markets, trade, and anticorruption efforts. In this way, rigorous accountancy is necessary to further accountability and transparency, as well as to promote economic development.

\section{Figure 4: Implementation vs Adoption}

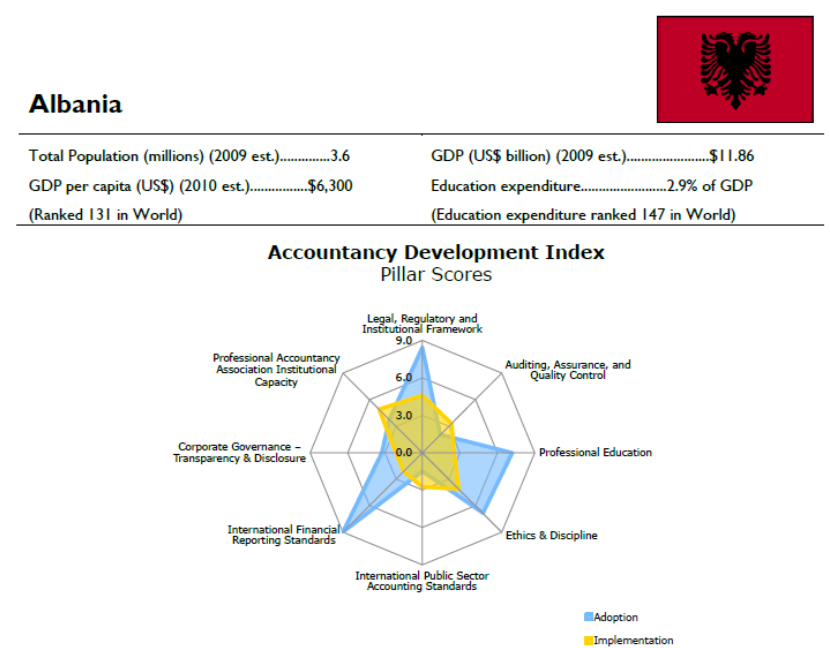

Source: Measuring Country-Level Accountancy Performance and Achievement Accountancy Development Index 


\section{Figure 5: ADI Sub-Pillar/Milestones Breakdown}

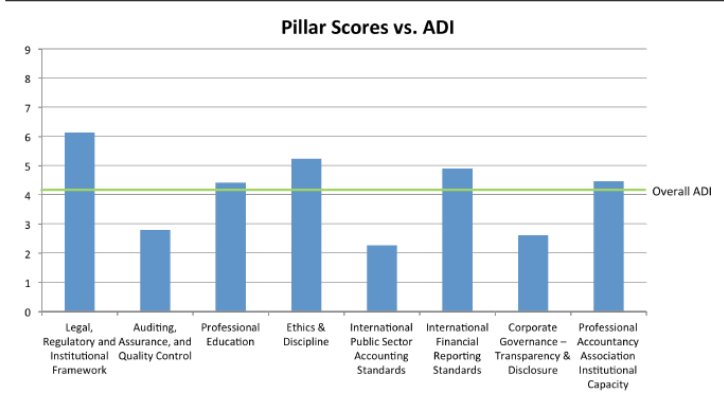

\section{Sorce: Measuring Country-Level Accountancy Performance and Achievement Accountancy Development Index}

The development of accountancy has not been uniform throughout the world. Just as accountancy influences society, culture, politics, economics and the judicial aspects of a country, these same aspects have influenced accountancy, causing its development to vary country by country this is also the case of Albania in which the implementation and the adoption are ilistratet in Figure 4. Although a great degree of variation still remains, the last decade has seen an increased tendency toward convergence among differing accountancy systems worldwide. Globalization, international trade, and supra-national legislation have been powerful forces behind this convergence. The result of these pressures has been the emergence of a generally agreed upon group of norms, ethics, and practices that exist and are recognized as international best practices in the area of accountancy.

Our country, as many reforms undertaken by countries in transition, has started the reforms in accounting field in cooperation with the World Bank, which was first finalised with the creation of the full National Accounting Standards set, which was first implemented in Albania in 2008. These reforms didn't stop but continued to fit EU requirements and directives by improving NAS ${ }^{1}$ and suitability with IFRS ${ }^{2}$ for $\mathrm{SME}^{3}$ which started to be implemented immediately.

Certainly that the cooperation of Albanian regulatory institutions is in it's continuity with the World Bank project where actually the cooperation field is accounting education as well.

Measuring and understanding the progress of a country toward international best practices for accountancy is important as this progress may enhance the effectiveness and efficiency of economic flows between countries, the ability of managers and investors to identify and shift resources from failing to successful projects, further good corporate governance by enhancing shareholder monitoring of management decisions and may reduce the external cost of capital ${ }^{4}$.

\section{Conclusion}

The IAESB has developed a comprehensive set of consistent, high-quality standards for educating professional accountants. This effort stretching back a decade or more to the former IFAC Education Committee has strengthened the essential third leg, together with financial reporting and auditing standards, of a strong global accounting profession. Educational programs in compliance with these standards will undoubtedly produce high quality professional accountants.

UNCTAD has produced the Guidelines as a global curriculum and has progressively evolved into an authoritative knowledge-based institution. In recent years it has been working on its Accounting development Tool to support developing nations. The third pillar covers human capacity for which the IES are used as benchmarks.

The process of uniformly implementing education standards globally is a challenging task. The Globalization Roundtables have pointed out many of the practical aspects of implementation. It is clear that implementation in many parts of the world

\footnotetext{
${ }^{1}$ National Accounting Standards in Albania

2 International Financial Reporting Standards

${ }^{3}$ Small and Medium Enterpise

${ }^{4}$ Busman and Smith in 2003 noted the three channels through which accounting information enhances economic growth.
} 
is a multi-year undertaking, requiring communication, resources, training, and benchmarking progress. In many countries, accountancy education is defined much more broadly than preparation for membership in IFAC member bodies. Accountants who become members of member bodies represent a minority of the accountants who graduate from educational institutions. In many countries, a minority of accounting educators are members of IFAC member bodies.

Increasingly research has addressed the global development of accountancy education. In this paper specific reference is made to comparative studies by Karreman and Needles (Karreman, 2002, 2006, 2007; Needles 1994, 2005, 2008, 2010, 2011). This research has identified numerous occasions of internationally compatible development. As such the present study is just another step in academic and professional support for the further development of the global financial infrastructure for which accountancy education of the right level and content is a necessary condition.

The development of accountancy has not been uniform throughout the world. Just as accountancy influences society, culture, politics, economics and the judicial aspects of a country, these same aspects have influenced accountancy, causing its development to vary country by country this is also the case of Albania in which the implementation and the adoption of IES are part of the World Bank project.

Our country, as many reforms undertaken by countries in transition, has started the reforms in accounting field in cooperation with the World Bank, which was first finalised with the creation of the full National Accounting Standards set, which was first implemented in Albania in 2008. These reforms didn't stop but continued to fit EU requirements and directives by improving NAS and suitability with IFRS for SME which started to be implemented immediately.

Certainly that the cooperation of Albanian regulatory institutions is in it's continuity with the World Bank project where actually the cooperation field is accounting education as well.

\section{References}

[1] IAESB, International Accounting Education Standards Board, International Federation of Accountants, Education

[2] Handbook of International Education Pronouncements, 2017 Edition, IAESB

[3] Changes of Substance from the 2015 Edition of the Handbook and Recent Developments

[4] National Association of State Boards of Accountancy (NASBA), Professor Dr Gert H. Karreman, Professor Belverd E. Needles Ph.D., CPA, CMA, A.M. Verweij page 8.

[5] IFAC, International Federation of Accountants, About IFAC, Membership \& Compliance Program, www.ifac.org

[6] Global Accountancy Education Recognition Study 2012 (NASBA 2013)Professor Dr Gert H. Karreman Professor Belverd E. Needles Ph.D., CPA, CMA, page 20

[7] Needles, B.E. Jr, (2008), "International Education Standards (IES): Issues of Implementation"

[8] WTO, World Trade Organization, www.wto.org 